\title{
Effect of Level of Metabolizable Protein on Splanchnic Flux of Amino Acids in Lactating Dairy Cows
}

\author{
G. Raggio, ${ }^{1}$ D. Pacheco, ${ }^{2, \star}$ R. Berthiaume, ${ }^{2}$ G. E. Lobley, ${ }^{3}$ D. Pellerin, ${ }^{1}$ \\ G. Allard, ${ }^{1}$ P. Dubreuil, ${ }^{4}$ and H. Lapierre ${ }^{2}$ \\ ${ }^{1}$ Département des Sciences Animales, \\ Université Laval, Ste-Foy, QC, Canada, G1K 7P4 \\ ${ }^{2}$ Dairy \& Swine Research and Development Centre, \\ Agriculture and Agri-Food Canada, Lennoxville, QC, Canada, J1M 1 Z3 \\ ${ }^{3}$ Rowett Research Institute, Aberdeen, UK, AB21 9SB \\ ${ }^{4}$ Faculté de Médecine Vétérinaire, Université de Montréal, \\ St-Hyacinthe, QC, Canada, J2S 7C6
}

\begin{abstract}
The response of splanchnic tissue metabolism to different levels of metabolizable protein (MP) was measured in 6 catheterized multiparous lactating Holstein cows. Three diets, balanced to provide similar energy intakes and increasing amounts of MP (g/d)-1922 (low), 2264 (medium), and 2517 (high)—were fed during 21-d experimental periods according to a replicated Latin square. On d 18,19 , or 20 , six hourly blood samples were collected simultaneously from the portal and hepatic veins plus an artery to determine net fluxes of nutrients across the portal-drained viscera and the liver. Yields of milk and protein increased, as did urinary $\mathrm{N}$ excretion with increasing MP. Portal absorption of essential amino acids (EAA) increased linearly with increasing MP supply, as did liver removal of His, Met, and Phe. In contrast, liver removal of the branchedchain AA (BCAA) and lysine was unaffected by diets. With increasing MP, the ratio of milk output to postliver supply of BCAA, Thr, and Lys decreased linearly, indicating oxidation of these AA in the peripheral tissues. Concomitant to a decreased catabolism of EAA in the liver (His, Met, Phe, and Thr) and/or in peripheral tissues (BCAA, Lys, and Thr), the efficiency of transfer of absorbed EAA into milk protein decreases markedly as protein supply increases. The efficiency of transfer of absorbed AA into milk also varies greatly between AA. These 2 important factors should be taken into account when building predictive schemes for milk protein output.
\end{abstract}

(Key words: amino acid, splanchnic tissue, mammary gland, cow)

Received December 6, 2003.

Accepted April 26, 2004.

Corresponding author: H. Lapierre; e-mail: lapierreh@agr.gc.ca.

*Current address: AgResearch Ltd., Private Bag 11008, Palmerston North, New Zealand.
Abbreviation key: BCAA = branched-chain AA, EAA = essential AA, MP = metabolizable protein, pAH $=$ para-aminohippurate, $\mathbf{P D V}=$ portal-drained viscera.

\section{INTRODUCTION}

Optimal conditions for milk production can be defined as either when output is maximized or when the transfer efficiency of dietary protein into milk protein is optimized. Maximizing output involves increasing dietary protein supply but, as the supply approaches current recommendations, the efficiency of transfer into milk protein decreases (Doepel et al., 2004). The highest transfer efficiencies, therefore, are achieved at low dietary protein supply but are associated with reduced yields. In practical terms, a well-advised feeding strategy would supply protein to achieve milk production between extremes of maximal output and efficiencies. Prediction of optimum supply requires knowledge of how alterations in that supply affect the partition of individual AA between catabolism and anabolism.

Increasing dietary protein supply usually results in higher portal absorption of AA in lactating cows (Bach et al., 2000; Blouin et al., 2002), although elevated CP intake may not lead to additional AA absorption if the energy supply is not adequate to support rumen microbial protein synthesis (Reynolds et al., 1992). Once absorbed, the AA flow to the liver. Although hepatic removal of AA was first proposed as a regulator of peripheral tissue anabolism (Reynolds et al., 1994), other evidence suggests that hepatic AA catabolism may instead respond to peripheral tissue requirements (Lobley and Lapierre, 2003; Ortigues-Marty et al., 2003). The question then is: To what extent can liver catabolism of AA be decreased-i.e., how much of the hepatic extraction of AA is obligatory (e.g., to support plasma protein synthesis or gluconeogenesis) and how much is nonobligate and susceptible to manipulation (e.g., can 
the amount removed be reduced)? This question can be answered by varying protein supply below and above requirements with examination of changes in the partition and efficiency of use of AA as the supply is altered. An additional consideration is that some AA are not exclusively, or even predominantly, catabolized by the liver.

Therefore, the current study investigates the impact of increasing metabolizable protein (MP) on hepatic removal of essential AA (EAA) and subsequent utilization of postsplanchnic supply by the mammary gland. Given that the efficiency of conversion of absorbed EAA into milk protein will be altered, these findings will lead to a better understanding of how splanchnic and postsplanchnic tissues coordinate to regulate AA metabolism.

\section{MATERIALS AND METHODS}

\section{Animals and Treatments}

Six multiparous Holstein cows, averaging $656 \pm 60$ $\mathrm{kg}$ BW and $96 \pm 8 \mathrm{DIM}$ at the beginning of the study, were used in a double $3 \times 3$ Latin square design, balanced for residual effects, with 21-d experimental periods. All cows were surgically implanted with vascular catheters across the splanchnic tissues (Huntington et al., 1989). Briefly, Teflon catheters encased in silastic were implanted into the portal vein and one hepatic vein, whereas Tygon catheters were inserted into 2 mesenteric veins and one in a mesenteric artery. The right carotid artery was also raised to a subcutaneous position to provide alternative access to arterial blood if necessary. Surgeries were performed at least 1 mo before the start of the experiment.

Three diets were formulated using the NRC (2001) to provide equal energy while increasing MP, averaging 1922 (low), 2264 (medium), or 2517 (high) g of MP/ d. Feeding different amounts of MP was achieved by substituting Megalac (Church \& Dwight Co., Inc., Princeton, NJ) with Prolak (H. J. Baker \& Bro. Inc., Westport, CT) (Tables 1 and 2). The amount of feed offered provided similar energy intake (36.4 Mcal $\mathrm{NE}_{\mathrm{L}}$ per d) throughout the study. The quantity of wet feed offered was adjusted weekly, based on the DM content of the grass silage (determined by drying at $105^{\circ} \mathrm{C}$ for $48 \mathrm{~h}$ ). Daily allowance was distributed in 12 equal meals every $2 \mathrm{~h}$ from automated feeders (Ankom, Fairport, NY), except long hay that was offered once a day. Orts, when present, were recorded daily. Cows had free access to water and were housed in a tie-stall barn, which was lit from 0600 to $2200 \mathrm{~h}$. They were milked twice daily (0600 and $1800 \mathrm{~h}$ ), and production was recorded at each milking. The experimental protocol was approved by the Institutional Committee for Animal Care
Table 1. Composition of the 3 dietary treatments with different levels of metabolizable protein (MP).

\begin{tabular}{lccc}
\hline & \multicolumn{3}{c}{ Treatments } \\
\cline { 2 - 4 } Ingredients & Low MP & Medium MP & High MP \\
g/kg of DM & 429 & 421 & 423 \\
\hline Grass silage & 0 & 28 & 54 \\
Prolak $^{1}$ & 243 & 243 & 234 \\
Soybean hulls & 148 & 148 & 143 \\
Corn grain, ground $_{\text {Megalac }^{2}}$ & 34 & 23 & 12 \\
Grass hay $_{\text {Molasses, beet sugar }}$ & 13 & 31 & 31 \\
Mineral and vitamin premix & 21 & 13 & 13 \\
Corn grain, cracked & 78 & 75 & 15 \\
Estimation from NRC (2001) & 32 & \\
NE & & & \\
CP, Mcal/d & 36.4 & 36.4 & 36.4 \\
RDP supplied, g/d & 12.7 & 14.7 & 16.6 \\
RDP balance, g/d & 2125 & 2307 & 2501 \\
RUP supplied, g/d & -162 & 4 & 182 \\
RUP balance, g/d & 907 & 1257 & 1602 \\
Metabolizable protein, g/d & -396 & -58 & 317 \\
$\quad$ From microbial protein & 1922 & 2264 & 2517 \\
From undegraded feed & 654 & 1251 & 1261 \\
From endogenous origin & 112 & 899 & 1140 \\
\hline
\end{tabular}

${ }^{1}$ H. J. Baker \& Bro. Inc., Westport, CT.

${ }^{2}$ Church \& Dwight Co., Inc., Princeton, NJ.

${ }^{3}$ Calculated using the intake (low MP: 23.8, medium MP: 24.2, high MP: $24.7 \mathrm{~kg} \mathrm{DM} / \mathrm{d}$ ) and the production observed during the study, with chemical composition of the feed ingredients reported in Table 2 .

of the Lennoxville Research Center, and animals were cared for according to the guidelines of the Canadian Council on Animal Care (1993).

\section{Sampling}

On d 13 to 18 of each period, total collection of feces and urine was made to determine $\mathrm{N}$ balance. Urine was collected in stainless steel containers via a Gouch tube (BF Goodrich Co., Kitchener, ON, Canada) and acidified twice daily with $50 \mathrm{~mL}$ of sulfuric acid to maintain $\mathrm{pH}$ below 3.0. A $2 \%$ portion of the feces and urine collected was sampled daily and frozen. At the end of the period, samples were thawed, mixed, subsampled, and frozen for further analyses. Any feed refusals were sampled daily. Milk samples were taken at each milking and frozen for later analysis.

On d 18, 19, or 20 (2 cows sampled per day), sodium p-aminohippurate (pAH; $100 \mathrm{~g} / \mathrm{L}$ ) was infused continuously $(14.4 \mathrm{~g} / \mathrm{h})$ into one mesenteric vein catheter using a syringe pump, preceded by a 2 -g priming dose. After at least $40 \mathrm{~min}$ of pAH infusion, simultaneous blood collections were taken hourly for $5 \mathrm{~h}(\mathrm{n}=6)$ from the arterial plus portal and hepatic vein catheters. Blood samples were collected from the mammary vein by venipuncture every other hour $(\mathrm{n}=3)$. Immediately after sampling, blood was transferred from the syringes to 
Table 2. Chemical composition of the feed ingredients.

\begin{tabular}{|c|c|c|c|c|c|c|}
\hline $\begin{array}{l}\text { Analyses } \\
(\mathrm{DM} \%)\end{array}$ & $\begin{array}{l}\text { Grass } \\
\text { silage }\end{array}$ & $\begin{array}{l}\text { Soybean } \\
\text { hulls }\end{array}$ & Grass hay & $\begin{array}{l}\text { Cracked } \\
\text { corn }\end{array}$ & $\begin{array}{l}\text { Ground } \\
\text { corn }\end{array}$ & Prolak \\
\hline $\mathrm{CP}$ & 17.40 & 11.70 & 14.20 & 8.10 & 8.30 & 77.60 \\
\hline $\mathrm{ADF}$ & 33.10 & 46.80 & 33.80 & 2.00 & 2.50 & 9.90 \\
\hline $\mathrm{NDF}$ & 41.40 & 66.00 & 54.20 & 9.50 & 10.40 & 19.70 \\
\hline Lignin & 5.20 & 8.90 & 3.00 & 0.50 & 0.60 & 8.70 \\
\hline ADFIP & 0.70 & 0.70 & 1.10 & 0.20 & 0.20 & 8.40 \\
\hline NDFIP & 3.00 & 2.90 & 4.50 & 0.70 & 0.80 & 12.50 \\
\hline Ash & 10.90 & 4.70 & 15.00 & 1.20 & 1.30 & 13.50 \\
\hline Starch & 1.90 & 2.30 & 2.40 & 71.50 & 76.00 & 0.40 \\
\hline Lipid & 1.50 & 0.80 & 2.50 & 2.90 & 1.30 & 6.90 \\
\hline \multicolumn{7}{|l|}{$\begin{array}{l}\text { Amino acid } \\
(\mathrm{g} \text { AA/100 g CP) }\end{array}$} \\
\hline Alanine & 4.69 & 3.68 & 5.20 & 7.78 & 6.63 & 6.59 \\
\hline Arginine & 3.09 & 4.47 & 3.68 & 4.75 & 4.46 & 5.84 \\
\hline Aspartate & 10.10 & 8.33 & 9.39 & 7.39 & 6.27 & 9.04 \\
\hline Cysteine & 0.71 & 1.67 & 1.01 & 2.77 & 2.05 & 2.24 \\
\hline Glutamate & 7.68 & 9.64 & 8.66 & 19.53 & 16.27 & 10.76 \\
\hline Glycine & 4.33 & 7.36 & 4.26 & 4.09 & 3.73 & 7.70 \\
\hline Histidine & 1.48 & 2.54 & 1.52 & 3.03 & 2.77 & 3.46 \\
\hline Isoleucine & 3.80 & 3.24 & 3.68 & 3.69 & 3.25 & 2.97 \\
\hline Leucine & 6.29 & 5.70 & 6.06 & 12.80 & 11.20 & 9.17 \\
\hline Lysine & 3.74 & 6.05 & 3.54 & 3.17 & 2.89 & 6.14 \\
\hline Methionine & 1.25 & 1.14 & 1.30 & 2.37 & 2.05 & 1.55 \\
\hline Phenylalanine & 3.92 & 3.33 & 3.97 & 4.75 & 4.46 & 4.98 \\
\hline Proline & 5.82 & 4.65 & 8.30 & 9.50 & 7.59 & 5.94 \\
\hline Serine & 3.68 & 5.26 & 3.54 & 5.15 & 4.58 & 5.83 \\
\hline Threonine & 3.62 & 3.16 & 3.61 & 3.96 & 3.37 & 3.93 \\
\hline Valine & 5.40 & 4.12 & 5.20 & 5.15 & 4.58 & 6.76 \\
\hline Total AA & 69.60 & 74.34 & 72.92 & 99.88 & 86.15 & 92.90 \\
\hline
\end{tabular}

heparinized tubes and kept on ice prior to centrifugation at $3000 \mathrm{rpm}$ for $12 \mathrm{~min}$ at $4^{\circ} \mathrm{C}$. The plasma was then subsampled for immediate analyses, and the remainder was stored at $-20^{\circ} \mathrm{C}$ for later analyses.

\section{Laboratory Analyses}

Feed ingredients, feed refusals, and feces were freezedried and ground to pass through a 1-mm screen. Nitrogen content of feed ingredients, refusals, and milk samples collected at each milking was determined by combustion (Nitrogen Determinator, model FP-428 LECO, St. Joseph, MI). Crude protein contents of feed and milk were calculated as $\mathrm{N} \times 6.25$ and $\mathrm{N} \times 6.38$, respectively. Urine and feces samples were analyzed for total $\mathrm{N}$ using the micro-Kjeldahl method (Tecator 1030, Hoganas Sweden; AOAC, 1996). Milk fat was measured according to the Roese-Gottlieb method (AOAC, 1996).

Noncasein $\mathrm{N}$ and nonprotein $\mathrm{N}$ in milk were analyzed with the micro-Kjeldahl method on pooled samples from the collection period. Noncasein $\mathrm{N}$ was obtained by precipitation of the caseins at $\mathrm{pH}$ 4.6. Nonprotein $\mathrm{N}$ was obtained by precipitation with TCA, with a final concentration of $12 \%$. Casein $\mathrm{N}$ is calculated by finding the difference between total $\mathrm{N}$ and noncasein $\mathrm{N}$, whereas whey protein is estimated by finding the difference between noncasein nitrogen and nonprotein $\mathrm{N}$. The $\mathrm{N}$ content was transposed into protein using the 6.38 factor. Casein profile was determined by inverse-phase HPLC on the pellet obtained when precipitating caseins at pH 4.6 (Jaubert et al., 1992).

Packed cell volume of each blood sample was determined by the microhematocrit method. Plasma concentrations of $\mathrm{pAH}$, urea, and ammonia were measured with an automatic analyzer (Technicon Autoanalyser II, Technicon Instruments Corporation, Tarrytown, NY) as previously described (Huntington, 1984) on fresh samples on the day of sampling.

For AA determination, samples of feed were predigested with performic acid to stabilize Met and Cys, treated with hydrobromic acid to destroy the performic acid, and then acid-hydrolyzed with $6 \mathrm{~N} \mathrm{HCl} \mathrm{(AOAC,}$ 1996: method \# 994 to 12), and AA were quantified by ion-exchange chromatography (Beckmann 6300, Palo Alto, CA). A separate acid hydrolysis $(6 \mathrm{~N} \mathrm{HCl})$ digestion procedure was conducted for Phe and His, because those AA are destroyed during the oxidation process and by reaction with bromine.

Plasma concentrations of EAA plus tyrosine were measured by the isotope dilution method (Calder et al., 1999). On the day of sampling, $0.2 \mathrm{~g}$ of an internal standard solution was added to $1 \mathrm{~g}$ of plasma. The internal standard solution was prepared with labeled AA diluted in $0.1 \mathrm{~N} \mathrm{HCl}$ with the following concentration 
$(\mu M)$ : DL-His- $\alpha-{ }^{15} \mathrm{~N}$ (182), L-Ile- ${ }^{15} \mathrm{~N}$ (713), L-Leu-1- ${ }^{13} \mathrm{C}$ (877), DL-Lys- $2-{ }^{15} \mathrm{~N}-2 \mathrm{HCl}$ (308), DL-Met-1- ${ }^{13} \mathrm{C}$ (98), LPhe- $1-{ }^{13} \mathrm{C}(226)$, L-Thr- ${ }^{15} \mathrm{~N}(45), \mathrm{L}^{-} \mathrm{Tyr}-{ }^{15} \mathrm{~N}$ (469), and LVal $-{ }^{15} \mathrm{~N}$ (846). Labeled AA (95 to 99 atom \%) were supplied by CDN isotopes (Montreal, QC, Canada) for His, Leu, Lys, Met, and Phe (Cambridge Isotope Laboratory, Andover, MA) for Ile, Thr, and Tyr (Isotec Inc., Miamisburg, $\mathrm{OH}$ ) for Val. Plasma samples with the internal standard were kept frozen at $-20^{\circ} \mathrm{C}$ until analyses. At the time of analysis, the plasma was deproteinized with sulfosalicylic acid (38\% wt/vol), the N-(tert-butyldimethyl) AA derivative prepared (Calder and Smith, 1988), and AA concentration determined by gas chromatography-mass spectrometry (model HP6890, S973 mass selective detector; Hewlett Packard, CA) based on the principles described by Calder et al. (1999).

\section{Calculations and Statistical Analyses}

Mean values for intake, production, and composition of milk, feces, and urine taken during the collection period were used for statistical analyses. Plasma flow across the splanchnic tissues was calculated from downstream dilution of pAH infusion (Katz and Bergman, 1969). If, within one sampling day, the CV of the mean plasma flow for an animal was greater than $15 \%$ due to only one sample, then this value was removed. Milk AA output was estimated using milk protein yield measured during the collection period, and AA composition was reported in the literature (Swaisgood, 1995). Mammary plasma flow was estimated according to the Fick principle using Phe and Tyr as internal markers (Mepham, 1982), with allowance for a 3.5\% contribution from bloodborne proteins: mammary plasma flow = $([$ milk Phe + Tyr $] \times 0.965) \div($ AV difference Phe + Tyr $)$ (Cant et al., 1993). Daily net fluxes of AA across the portal-drained viscera (PDV), liver, total splanchnic tissues, and mammary gland were calculated for each cow as the product of the average venous-arterial concentration difference and the average plasma flow measured for that day. Blood flow was calculated as plasma flow divided by ( 1 - packed cell volume). Net fluxes of ammonia were calculated using plasma concentrations and blood flow, whereas urea fluxes were calculated using plasma concentrations and blood water flows. Blood water flow was calculated as blood flow multiplied by the ratio of the $(1-\mathrm{DM})$ of blood on plasma (Milano et al., 2000). A negative flux indicates utilization or removal, whereas a positive flux indicates net production or release of the nutrient across the tissue. One cow did not have a patent hepatic catheter, and results obtained for portal vein absorption strongly suggested a misplacement of this catheter; all results for this cow were discarded. One cow could not be used for her third period (treatment was high MP), as she had severe mastitis. Therefore, $\mathrm{n}=5$ for low and medium MP and $\mathrm{n}=4$ for high MP.

Data were analyzed statistically according to a replicated Latin square design using the GLM procedure (SAS Institute Inc., 1996), with treatment, period, and cow as the main effects. Treatments were compared with linear and quadratic polynomial contrasts. A linear component indicates that the difference between the first and last levels is significant, whereas a quadratic component will indicate the lack of fit of the intermediary level for a linear relationship (Gill, 1978). Treatment differences were considered significant if $P<0.10$ and as a trend for $0.10<P<0.20$.

\section{RESULTS}

\section{Milk Production and Composition}

Milk production and composition data are presented in Table 3. Milk production increased linearly $(P=0.02)$ with increasing the supply of MP. Milk CP yield also increased linearly $(P=0.01)$, as did each protein fraction yields. Milk CP concentration increased linearly $(P=0.09)$, but the proportion of true protein decreased $(P<0.01)$, mainly due to a decrease in the proportion of the casein fraction $(P=0.03)$. The casein profile was not affected by diet (Table 3). Milk fat concentration decreased linearly $(P=0.01)$ resulting in a decrease in fat yield at the highest MP level (linear: $P=0.09$; quadratic: $P=0.10)$. In this experiment, the low MP diets contained more Megalac (Table 1), and the yield and percentage of fat were higher with this diet. Similarly, Petit (2002) reported an increment of fat percentage with a diet supplement with Megalac, compared with other isoenergetic and isonitrogenous diets.

\section{Net Flux of Essential Amino Acids}

Plasma flow across the PDV and the splanchnic tissue was not affected by MP supply and averaged 1321, 1271, and $1236 \pm 43.2$ and 1676, 1608, and $1647 \pm 63.0 \mathrm{~L} / \mathrm{h}$, for low, medium, and high MP, respectively. However, plasma flow across the mammary gland increased at high MP compared with low and medium MP (linear and quadratic components, $P=0.04$ ), averaging 515, 491 , and $607 \pm 24.1 \mathrm{~L} / \mathrm{h}$, for low, medium, and high MP, respectively. As MP intake was raised, plasma arterial concentrations (Table 4) of His, Ile, Leu, Lys, and Val increased linearly $(P<0.10)$ with a quadratic effect for Lys $(P=0.01)$ and His $(P=0.14)$. Net fluxes of EAA and Tyr across the PDV, liver, splanchnic tissue, mammary gland, and in milk are presented in Table 5. With increasing MP supply, the PDV net flux increased linearly $(P<0.10)$ for all measured AA, with a quadratic effect 
Table 3. Effect of metabolizable protein (MP) supply on milk production and composition in Holstein cows. ${ }^{1}$

\begin{tabular}{|c|c|c|c|c|c|c|}
\hline \multirow[b]{2}{*}{ Milk } & \multicolumn{3}{|c|}{ Treatments } & \multirow[b]{2}{*}{ SEM } & \multicolumn{2}{|c|}{$P^{2}$} \\
\hline & Low MP & Med MP & High MP & & Linear & Quadratic \\
\hline Production, kg/d & 33.9 & 35.7 & 36.2 & 0.49 & 0.02 & 0.30 \\
\hline Crude protein yield, g/d & 838 & 905 & 962 & 15.0 & $<0.01$ & 0.80 \\
\hline True protein yield, g/d & 802 & 853 & 902 & 14.1 & $<0.01$ & 0.95 \\
\hline Casein yield, g/d & 629 & 659 & 689 & 6.0 & $<0.01$ & 0.99 \\
\hline Whey protein yield, g/d & 173 & 194 & 212 & 9.2 & 0.03 & 0.90 \\
\hline Non protein $\mathrm{N}$ yield, g/d & 38 & 52 & 60 & 1.5 & $<0.01$ & 0.10 \\
\hline Crude protein, \% & 2.46 & 2.53 & 2.65 & 0.069 & 0.09 & 0.72 \\
\hline True protein, \% of $\mathrm{CP}$ & 95.5 & 94.3 & 93.8 & 0.16 & $<0.01$ & 0.11 \\
\hline Casein, $\%$ of $\mathrm{CP}$ & 74.7 & 72.8 & 71.9 & 0.68 & 0.03 & 0.55 \\
\hline Whey protein, \% of CP & 20.8 & 21.5 & 21.9 & 0.68 & 0.28 & 0.82 \\
\hline Nonprotein $\mathrm{N}, \%$ of $\mathrm{CP}$ & 4.5 & 5.7 & 6.2 & 0.16 & $<0.01$ & 0.11 \\
\hline \multicolumn{7}{|l|}{ Casein profile, $\%$ of casein } \\
\hline kappa & 9.4 & 9.4 & 9.3 & 0.32 & 0.72 & 0.89 \\
\hline alpha s1 & 45.9 & 45.7 & 45.9 & 0.42 & 0.99 & 0.68 \\
\hline alpha-s2 & 5.6 & 5.2 & 6.8 & 0.61 & 0.19 & 0.18 \\
\hline gamma & 4.7 & 5.1 & 4.3 & 0.30 & 0.30 & 0.12 \\
\hline beta, total & 34.4 & 34.7 & 34.2 & 0.46 & 0.70 & 0.48 \\
\hline Fat yield, g/d & 1216 & 1318 & 1199 & 39.7 & 0.14 & 0.17 \\
\hline Fat concentration, $\%$ & 3.76 & 3.65 & 3.29 & 0.104 & 0.02 & 0.30 \\
\hline
\end{tabular}

for Met $(P=0.03)$ and Lys $(P=0.20)$. Hepatic removal increased linearly $(P<0.04)$ for His, Met, Phe, and Tyr and tended $(P<0.19)$ to increase for Thr. The net flux of EAA across the splanchnic tissue increased linearly $(P<0.10)$ for Ile, Leu, Lys, Thr, and Val, with a quadratic trend $(P<0.20)$ for His, Ile, Leu, Lys, and Met. Mammary gland uptake increased linearly $(P<0.10)$ for all BCAA, Lys, and Phe, with a tendency for a linear increase for Met $(P<0.14)$. Output in milk increased linearly $(P<0.01)$ for all AA, as did milk CP yield (Table 3 ). The ratio of milk output/PDV net flux decreased linearly $(P<0.10)$ for His, Ile, Leu, Lys, Met, Phe, and Tyr and tended to decrease linearly $(P<0.20)$ for Thr and Val (Table 6). In addition, the ratio of the liver flux to portal flux increased linearly $(P<0.10)$ with MP supply for Met, Phe, and Tyr or only with a tendency $(P=0.15)$ for His. Relative to total hepatic influx, hepatic net removal of Met, Phe, and Tyr increased linearly $(P<0.10)$, whereas His tended to increase $(P=$ 0.14 ; Table 7).

\section{Urea and Ammonia}

Splanchnic urea flux tended to increase $(P<0.12)$ with increasing MP supply as a result of a decreased return of urea into the PDV $(P=0.06)$ and a numerical increase in hepatic ureagenesis $(P=0.22$; Table 8$)$. Accordingly, arterial urea-N concentration increased

Table 4. Effect of metabolizable protein (MP) supply on arterial concentration of amino acids $(\mu M)$ in Holstein cows. ${ }^{1}$

\begin{tabular}{lccccccc}
\hline & \multicolumn{3}{c}{ Treatments } & & & \multicolumn{2}{c}{$P^{2}$} \\
\cline { 2 - 4 } \cline { 6 - 7 } & Low MP & Med MP & High MP & SEM & Linear & Quadratic \\
\hline Histidine & 49.0 & 60.2 & 58.7 & 3.06 & 0.09 & 0.14 \\
Isoleucine & 121.7 & 129.7 & 132.3 & & 2.08 & 0.02 & 0.32 \\
Leucine & 155.6 & 192.6 & 218.5 & & 4.11 & $<0.01$ & 0.31 \\
Lysine & 84.9 & 98.5 & 95.2 & & 1.90 & 0.01 & 0.01 \\
Methionine & 21.8 & 22.5 & 22.0 & & 1.06 & 0.91 & 0.61 \\
Phenylalanine & 57.1 & 58.4 & 63.1 & & 2.74 & 0.20 & 0.63 \\
Threonine & 114.1 & 116.9 & 110.0 & & 3.96 & 0.52 & 0.34 \\
Tyrosine & 56.4 & 59.6 & 58.9 & & 2.07 & 0.45 & 0.46 \\
Valine & 246.0 & 315.3 & 372.9 & & 8.45 & $<0.01$ & 0.58 \\
\hline
\end{tabular}

${ }^{1}$ Least square means presented with pooled SEM (given for $\mathrm{n}=4$ ); $\mathrm{n}=5$ for low and medium HP and $\mathrm{n}=4$ for high MP.

${ }^{2}$ Probability corresponding to the null hypothesis, with linear and quadratic contrasts. 
Table 5. Effect of metabolizable protein (MP) supply on net fluxes of amino acids $(\mathrm{mmol} / \mathrm{h})$ in Holstein cows. ${ }^{1}$

\begin{tabular}{|c|c|c|c|c|c|c|c|}
\hline \multirow[b]{2}{*}{ Amino acid } & \multirow[b]{2}{*}{ Tissue $^{2}$} & \multicolumn{3}{|c|}{ Treatments } & \multirow[b]{2}{*}{ SEM } & \multicolumn{2}{|c|}{$P^{3}$} \\
\hline & & Low MP & Medium MP & High MP & & Linear & Quadratic \\
\hline \multirow[t]{5}{*}{ Histidine } & PDV & 7.8 & 12.0 & 14.2 & 0.92 & $<0.01$ & 0.39 \\
\hline & HEP & -3.0 & -4.4 & -7.2 & 0.80 & 0.01 & 0.48 \\
\hline & $\mathrm{TSP}$ & 4.8 & 7.5 & 7.0 & 0.89 & 0.17 & 0.18 \\
\hline & MG & -6.6 & -6.6 & -6.9 & 0.38 & 0.64 & 0.72 \\
\hline & MILK & 6.1 & 6.6 & 7.0 & 0.11 & $<0.01$ & 0.80 \\
\hline \multirow[t]{5}{*}{ Isoleucine } & PDV & 21.0 & 26.6 & 28.8 & 1.27 & $<0.01$ & 0.31 \\
\hline & HEP & 2.6 & 4.4 & 1.6 & 1.47 & 0.69 & 0.23 \\
\hline & TSP & 23.5 & 30.8 & 30.5 & 0.92 & $<0.01$ & 0.02 \\
\hline & MG & -17.0 & -19.9 & -22.4 & 0.96 & 0.01 & 0.89 \\
\hline & MILK & 15.7 & 17.0 & 18.0 & 0.28 & $<0.01$ & 0.80 \\
\hline \multirow[t]{5}{*}{ Leucine } & PDV & 35.6 & 43.2 & 49.6 & 1.62 & $<0.01$ & 0.75 \\
\hline & HEP & 1.0 & 6.0 & 2.4 & 2.68 & 0.75 & 0.23 \\
\hline & TSP & 36.6 & 49.1 & 52.0 & 1.82 & $<0.01$ & 0.07 \\
\hline & MG & -28.3 & -32.1 & -38.3 & 1.72 & 0.01 & 0.56 \\
\hline & MILK & 26.1 & 28.2 & 29.9 & 0.47 & $<0.01$ & 0.57 \\
\hline \multirow[t]{5}{*}{ Lysine } & PDV & 29.1 & 38.0 & 40.2 & 1.95 & $<0.01$ & 0.20 \\
\hline & HEP & -0.1 & 0.9 & -4.9 & 2.44 & 0.24 & 0.29 \\
\hline & TSP & 29.0 & 38.5 & 35.5 & 1.26 & 0.02 & $<0.01$ \\
\hline & $\mathrm{MG}$ & -24.9 & -26.5 & -30.1 & 0.36 & 0.01 & 0.41 \\
\hline & MILK & 19.9 & 21.4 & 22.7 & 0.04 & $<0.01$ & 0.80 \\
\hline \multirow[t]{5}{*}{ Methionine } & PDV & 10.0 & 13.5 & 14.3 & 0.38 & $<0.01$ & 0.03 \\
\hline & HEP & -3.0 & -4.2 & -6.6 & 0.59 & 0.01 & 0.44 \\
\hline & TSP & 7.0 & 9.3 & 7.7 & 0.62 & 0.50 & 0.04 \\
\hline & MG & -6.6 & -6.9 & -7.9 & 0.48 & 0.14 & 0.62 \\
\hline & MILK & 6.6 & 7.0 & 7.5 & 0.12 & $<0.01$ & 0.80 \\
\hline \multirow[t]{5}{*}{ Phenylalanine } & PDV & 24.4 & 29.8 & 35.4 & 1.35 & $<0.01$ & 0.96 \\
\hline & HEP & -11.8 & -15.1 & -20.7 & 1.25 & $<0.01$ & 0.47 \\
\hline & TSP & 12.6 & 14.7 & 14.8 & 1.38 & 0.35 & 0.57 \\
\hline & MG & -11.1 & -12.0 & -13.1 & 0.62 & 0.09 & 0.96 \\
\hline & MILK & 10.4 & 11.2 & 11.9 & 0.19 & $<0.01$ & 0.80 \\
\hline \multirow[t]{5}{*}{ Threonine } & PDV & 20.4 & 23.8 & 34.5 & 2.70 & $<0.01$ & 0.30 \\
\hline & HEP & -6.7 & -6.6 & -14.5 & 3.48 & 0.19 & 0.36 \\
\hline & TSP & 13.7 & 17.5 & 19.9 & 1.87 & 0.07 & 0.77 \\
\hline & MG & -11.8 & -13.8 & -13.2 & 0.84 & 0.33 & 0.26 \\
\hline & MILK & 12.6 & 13.6 & 14.5 & 0.23 & $<0.01$ & 0.80 \\
\hline \multirow[t]{5}{*}{ Tyrosine } & $\mathrm{PDV}$ & 18.5 & 21.6 & 24.1 & 1.11 & 0.02 & 0.84 \\
\hline & HEP & -8.6 & -11.4 & -14.0 & 1.33 & 0.04 & 0.99 \\
\hline & TSP & 9.8 & 10.1 & 10.1 & 0.83 & 0.85 & 0.86 \\
\hline & MG & -8.8 & -9.9 & -9.8 & 0.70 & 0.41 & 0.49 \\
\hline & MILK & 10.8 & 11.7 & 12.4 & 0.19 & $<0.01$ & 0.80 \\
\hline \multirow{5}{*}{ Valine } & PDV & 28.4 & 34.4 & 40.5 & 3.51 & 0.07 & 0.98 \\
\hline & HEP & 1.3 & 5.3 & 6.2 & 2.77 & 0.29 & 0.65 \\
\hline & TSP & 29.7 & 39.5 & 46.8 & 4.51 & 0.05 & 0.82 \\
\hline & MG & -20.0 & -27.0 & -28.0 & 2.40 & 0.07 & 0.33 \\
\hline & MILK & 19.7 & 21.2 & 22.6 & 0.35 & $<0.01$ & 0.80 \\
\hline
\end{tabular}

${ }^{1}$ Least square means presented with pooled SEM (given for $\mathrm{n}=4$ ); $\mathrm{n}=5$ for low and medium HP and $\mathrm{n}=4$ for high MP.

${ }^{2} \mathrm{PDV}=$ Portal-drained viscera; HEP = hepatic; TSP = total splanchnic tissue; $\mathrm{MG}=$ mammary gland.

${ }^{3}$ Probability corresponding to the null hypothesis, with linear and quadratic contrasts.

linearly $(P<0.01)$ with an increasing supply of MP (Table 5). Arterial ammonia concentrations were unaffected by an MP supply, but ammonia flux across the PDV increased linearly and quadratically $(P=0.03)$ with an increased MP of the ration. Hepatic removal also increased linearly $(P=0.02)$, resulting in no effect of the diet on splanchnic net flux of ammonia.

\section{N Balance}

The planned increase in $\mathrm{N}$ intake $(P<0.01)$ was matched by increased $\mathrm{N}$ excretion in feces and in urine (linear contrast, $P<0.05$; Table 9). Apparent $\mathrm{N}$ digestibility also increased linearly $(P<0.02)$, averaging 53.2, 58.9 , and $60.5 \%$ for low, medium, and high MP, respectively. Nitrogen in milk as a proportion of $\mathrm{N}$ intake decreased $(P<0.02)$ with increasing $\mathrm{N}$ intake, averaging $27.5,25.6$, and $24.1 \%$ of $\mathrm{N}$ intake. In contrast, $\mathrm{N}$ retention was not affected by treatments (Table 9 ).

\section{DISCUSSION}

A recent review of studies in which AA were infused postruminally in dairy cows supports the concept that 
Table 6. Effect of metabolizable protein (MP) supply on the ratio of amino acids in milk protein relative to portal absorption. ${ }^{1}$

\begin{tabular}{llllllll}
\hline & \multicolumn{3}{c}{ Treatments } & & & \multicolumn{2}{c}{$P^{2}$} \\
\cline { 2 - 4 } \cline { 7 - 8 } Amino acid & Low MP & Medium MP & High MP & SEM & & Linear & Quadratic \\
\hline Histidine & 0.84 & 0.53 & 0.48 & 0.07 & 0.01 & 0.25 \\
Isoleucine & 0.81 & 0.62 & 0.57 & 0.07 & 0.08 & 0.52 \\
Leucine & 0.77 & 0.64 & 0.56 & 0.06 & 0.06 & 0.77 \\
Lysine & 0.74 & 0.56 & 0.49 & 0.07 & 0.08 & 0.45 \\
Methionine & 0.67 & 0.54 & 0.32 & 0.06 & 0.07 & 0.56 \\
Phenylalanine & 0.44 & 0.36 & 0.40 & 0.10 & 0.03 & 0.74 \\
Threonine & 0.67 & 0.63 & 0.52 & 0.09 & 0.06 & 0.51 \\
Tyrosine & 0.81 & 0.59 & 0.49 & 0.05 & 0.19 & 0.87 \\
Valine & 0.61 & 0.53 &
\end{tabular}

${ }^{1}$ Least square means presented with pooled SEM (given for $\mathrm{n}=4$ ); $\mathrm{n}=5$ for low and medium HP and $\mathrm{n}=4$ for high MP.

${ }^{2}$ Probability corresponding to the null hypothesis, with linear and quadratic contrasts.

the transfer of incremental AA supply into milk protein diminishes as supply approaches requirements (Doepel et al., 2004). Similarly, in this experiment, although the secretion of $\mathrm{N}$ into milk was elevated by increased MP supply, the efficiency of conversion of $\mathrm{N}$ intake into milk decreased when $\mathrm{N}$ intake increased. Similar results have also been observed by Wright et al. (1998) and Castillo et al. (2001). The marginal recovery of incremental MP supply in milk protein averaged 19\% between low and high MP, which is within the range of recovery from casein infusions (21\%) reviewed by Hanigan et al. (1998).

Therefore, although most formulation schemes focus on estimating the supply of protein at the duodenum and use fixed factors to predict transfer from absorption to metabolic usage, metabolic events differ between cows receiving a low vs. a high supply of protein. Exami- nation of the fate of $\mathrm{AA}$ between absorption, transit across the liver, and secretion in milk will help explain the mechanisms that result in higher transfer efficiency in cows receiving a lower MP supply.

\section{Amino Acid Flux}

As expected, increased MP supply resulted in elevated portal absorption of EAA, consistent with previous reports for dairy cows (Bach et al., 2000; Blouin et al., 2002). Indeed, the measured portal absorption matched prediction of digestible AA (NRC, 2001), corrected for endogenous contribution to the duodenal supply. The ratios between the NRC predictions and measured values were averaged for His (1.03), Lys (1.02), Ile (1.14), Leu (1.24), Val (1.13), and Thr (1.27). These ratios would conform to the concept of little or no catabo-

Table 7. Effect of metabolizable protein (MP) supply on the ratio of the hepatic net removal of amino acids relative to portal absorption and total influx. ${ }^{1}$

\begin{tabular}{lllllllll}
\hline & & \multicolumn{3}{c}{ Treatments } & & \multicolumn{2}{c}{$P^{3}$} \\
\cline { 3 - 5 } \cline { 7 - 8 } Amino acid & Ratio $^{2}$ & Low MP & Medium MP & High MP & SEM & Linear & Quadratic \\
\hline \multirow{2}{*}{ Histidine } & PDV & 0.346 & 0.380 & 0.506 & 0.063 & 0.15 & 0.56 \\
\multirow{2}{*}{ Methionine } & INFLUX & 0.033 & 0.041 & 0.065 & 0.012 & 0.14 & 0.59 \\
& PDV & 0.280 & 0.296 & 0.443 & 0.040 & 0.08 & 0.32 \\
Phenylalanine & INFLUX & 0.065 & 0.082 & 0.126 & 0.013 & 0.03 & 0.47 \\
\multirow{2}{*}{ Threonine } & PDV & 0.466 & 0.513 & 0.581 & 0.030 & 0.09 & 0.81 \\
& INFLUX & 0.093 & 0.122 & 0.146 & 0.007 & $<0.01$ & 0.74 \\
Tyrosine & PDV & 0.283 & 0.193 & 0.444 & 0.120 & 0.42 & 0.29 \\
& INFLUX & 0.038 & 0.037 & 0.065 & 0.018 & 0.38 & 0.53 \\
& PDV & 0.445 & 0.526 & 0.576 & 0.091 & 0.08 & 0.77 \\
& INFLUX & 0.075 & 0.099 & 0.111 & 0.009 & 0.05 & 0.62 \\
\hline
\end{tabular}

\footnotetext{
${ }^{1}$ Least square means presented with pooled SEM (given for $\mathrm{n}=4$ ); $\mathrm{n}=5$ for low and medium HP and $\mathrm{n}=4$ for high MP; given for AA showing a net hepatic removal.

${ }^{2}$ Ratio of hepatic removal on PDV: net portal flux; or on INFLUX: total liver influx = (portal plasma flow $\times$ portal concentration $)+($ arterial plasma flow $\times$ arterial concentration $)$.

${ }^{3}$ Probability corresponding to the null hypothesis, with linear and quadratic contrasts.
} 
lism of His and Lys across the gut in the ruminant, but substantial oxidation of the BCAA and loss of Thr through endogenous secretions into the digestive tract (Lobley and Lapierre, 2003). The ratios (NRC predicted/ observed) for Met (0.84) and Phe (0.79) were lower than unity, which was unexpected since limited oxidation by the ovine gut has been reported for Met (Lobley et al., 2003). Thus, one explanation would be an underestimation of the duodenal supply of these AA with the NRC (2001) model.

The increased absorption with increased MP was concomitantly associated with increased hepatic removal, both in absolute amount for His, Met, Phe, and Thr, and relative to portal absorption or total liver influx for His, Met, and Phe. On the other hand, hepatic removals of the BCAA and Lys were unaffected by diet. These data are consistent with the concept that the liver is a major site of catabolism for His, Met, Phe, and Thr and removes excess AA not used for peripheral anabolism. In contrast, for the BCAA and Lys, catabolism occurs to a greater extent in nonsplanchnic tissues. These observations agree with the localization of enzymes responsible for AA catabolism. Enzymes for His, Met, and Phe catabolism are almost exclusively restricted to hepatic tissues (see Lobley, 2002). In contrast, enzymes responsible for BCAA catabolism are spread across many tissues (Goodwin et al., 1987; DeSantiago et al., 1998), and recent studies have identified lysine ketoglutarate reductase and saccharopine dehydrogenase in the brain, kidney, and muscle of piglets (Pink et al., 2003).

Hepatic removal of EAA varied greatly between EAA, as previously observed in many species, including dairy cows (Bach et al., 2000; Blouin et al., 2002). Relative to net portal absorption, the highest fractional hepatic removal was for Phe (0.52) followed by His (0.42), Met (0.36), and Thr (0.34). At low MP supply, there was no net removal of Lys, but at high MP supply, hepatic removal averaged $12 \%$ of portal absorption. There was no net removal and even a positive numeric flux for the BCAA across the liver, as previously observed in dairy cows (Wray-Cahen et al., 1997; Bach et al., 2000; Blouin et al., 2002), but hepatic-portal differences were not different from zero. Although the magnitude of hepatic removal relative to portal absorption was lower in the current study, as would be expected due to increased metabolic demand for absorbed AA during lactation, the ranking among EAA agrees with previous observations in growing cattle (Lapierre et al., 2000), nonlactating cows (Wray-Cahen et al., 1997), and sheep (Lobley et al., 2001).

Only for His, and only at low MP, were mammary uptake and milk output higher than net splanchnic flux. This means that for all other measured AA, even at the low MP supply, postliver supply was sufficient to account for mammary uptake and milk protein output. This maintenance of lactation at a high level when supply was reduced was achieved by a substantial reduction of AA catabolism, sufficient to ensure no need for contribution of body protein "reserves." Such reductions in catabolism will have a finite limit, however, based on obligate needs for production of various metabolites, synthesis of hepatic export proteins (Raggio et al., 2002) and basal (cannot be manipulated) ureagenesis. For His, the limit in the reduction of hepatic removal (3.3\% of total liver influx at low MP intake) might have been reached, as an additional endogenous source must have been necessary to cover mammary gland uptake. This was not from mobilized body protein reserves as $\mathrm{N}$ retention was not decreased at low MP intake. One alternative are the His dipeptides, particularly carnosine, present in millimolar quantities in muscle and known to become depleted when animals are fed a diet low in His (Amend et al., 1979). Such sources would provide only a medium-term store and such a situation could not be sustained for a whole lactation cycle. Such constraints are a feature of the AA composition of the MP supply and the current observation was not surprising considering that His has been found to be limiting when grass silage was fed to dairy cows (Vanhatalo et al., 1999). This emphasizes the need to consider the amount and composition of AA supplied, rather than simply MP, when attempting to predict dietary responses and efficiencies.

Postliver supply of the BCAA and Lys substantially exceeded both mammary gland uptake and milk output. Earlier studies have shown that the mammary gland catabolizes Leu (Bequette et al., 1996; Thivierge et al., 2002), with this oxidation decreasing when Leu supply was low (Bequette et al., 1996). This is supported by the current observation, as the ratio of milk output to mammary uptake for the 3 BCAA decreased with increasing MP supply. Excess EAA-N extracted by the mammary gland relative to milk output is needed to support synthesis of nonessential AA, for which the uptake by the mammary gland is insufficient to account for milk output. Recently, the incorporation of lysine${ }^{15} \mathrm{~N}$ into nonessential AA within the mammary gland has been demonstrated in dairy cows (Lapierre et al., 2003).

Together, these metabolic events across the liver and the mammary gland explain why the ratios of transfer of absorbed AA into milk protein alter with MP supply (Table 7). At low MP supply, improved efficiency is achieved through a decreased hepatic removal of His, Met, Phe, and Thr, and, probably, decreased oxidation of the BCAA, Lys, and Thr in peripheral tissues. As MP supply is decreased, the liver, peripheral tissue, 
Table 8. Effect of metabolizable protein (MP) supply on arterial concentrations (mM) and splanchnic flux $(\mathrm{mmol} / \mathrm{h})$ of urea and ammonia in Holstein cows. ${ }^{1}$

\begin{tabular}{|c|c|c|c|c|c|c|c|c|}
\hline \multirow[b]{2}{*}{ Metabolite } & & \multirow[b]{2}{*}{ Tissue $^{2}$} & \multicolumn{3}{|c|}{ Treatments } & \multirow[b]{2}{*}{ SEM } & \multicolumn{2}{|c|}{$P^{3}$} \\
\hline & & & Low MP & Medium MP & High MP & & Linear & Quadratic \\
\hline \multirow[t]{4}{*}{ Ammonia } & Concentration & & 0.10 & 0.08 & 0.10 & 0.02 & 0.99 & 0.44 \\
\hline & Flux & PDV & 265 & 383 & 396 & 15.4 & $<0.01$ & 0.03 \\
\hline & & HEP & -249 & -361 & -390 & 29.3 & 0.02 & 0.28 \\
\hline & & TSP & 16 & 22 & 6 & 29.8 & 0.84 & 0.76 \\
\hline \multirow{4}{*}{ Urea-N } & Concentration & & 4.4 & 6.3 & 8.7 & 0.27 & $<0.01$ & 0.43 \\
\hline & Flux & PDV & -404 & -333 & -174 & 64.3 & 0.06 & 0.58 \\
\hline & & HEP & 881 & 1202 & 1258 & 183.0 & 0.22 & 0.56 \\
\hline & & TSP & 476 & 869 & 1083 & 218.5 & 0.12 & 0.74 \\
\hline
\end{tabular}

${ }^{1}$ Least square means presented with pooled SEM (given for $\mathrm{n}=4$ ); $\mathrm{n}=5$ for Low and Med HP and $\mathrm{n}=$ 4 for High MP.

${ }^{2} \mathrm{PDV}=$ Portal-drained viscera $; \mathrm{HEP}=$ hepatic TSP $=$ total splanchnic tissue.

${ }^{3}$ Probability corresponding to the null hypothesis, with linear and quadratic contrasts.

and mammary gland events combine to increase the partial efficiency of transfer of absorbed AA into milk. The design of this study does not resolve whether the liver was responding to, or controlling use by, peripheral tissues (see Lobley and Lapierre, 2003), but it is obvious that liver catabolism of His, Met, and Phe was tightly related with mammary requirements. Nonetheless, prediction of milk output based on duodenal MP or AA supply cannot rely on a fixed ratio of transfer, but rather needs to account for the efficiency of utilization of individual AA, which decrease as supply approaches requirements. Moreover, use of a common factor of transfer of MP into milk protein also implies that all AA are used with similar efficiency. In practice, efficiency of conversion of absorbed EAA (excluding His) into milk varied widely ( 0.42 to 0.78 ; Table 7 ) at the low MP supply, where efficiency was greatest. Phenylalanine always ranked the lowest, probably because supply was in excess of demand with these diets. This variation in efficiency among AA emphasizes the uniqueness of each $\mathrm{AA}$ and the importance of developing prediction equations for milk protein output based on the supply of individual AA rather than their total agglomeration as protein.

\section{Urea and Ammonia}

Net portal flux of ammonia increased with increasing MP supply and increased rumen degradable protein supply, as previously reported (Bach et al., 2000; Blouin et al., 2002), although urea recycled to the PDV decreased at high MP. All the extra ammonia absorbed was removed by the liver and, combined with increased hepatic removal of some AA, resulted in a numerically higher hepatic ureagenesis for the cows fed the highMP diet. Lapierre and Lobley (2001) calculated the ratio between hepatic ureagenesis and digestible $\mathrm{N}$; in growing cattle, this ranged from 0.49 to 1.78 (mean 0.93), and in lactating dairy cows, from 0.43 to 1.23 (mean 0.88 ). In the current experiment, the ratio of ureagenesis and digestible $\mathrm{N}$ averaged 1.17, again indicating the magnitude of the transit of $\mathrm{N}$ into the urea pool and the impact of recycling. Although arterial urea concentrations were higher with the high-MP diet, the recycling of urea into the PDV decreased with increasing MP, averaging $0.46,0.28$, and 0.14 of hepatic ureagenesis for low, med, and high MP, respectively. This suggests that entry of urea into the digestive tract is not simply a function of plasma concentration as previously

Table 9. Effect of metabolizable protein (MP) supply on nitrogen balance (g/d) in Holstein cows. ${ }^{1}$

\begin{tabular}{llllrlrl}
\hline & \multicolumn{3}{c}{ Treatments } & & \multicolumn{2}{c}{$P^{2}$} \\
\cline { 2 - 4 } \cline { 3 - 4 } Nitrogen & Low MP & Medium MP & High MP & SEM & Linear & Quadratic \\
\hline Intake & 475 & 550 & 624 & 6.1 & $<0.01$ & 0.98 \\
Feces & 222 & 226 & 246 & & 9.3 & 0.05 & 0.32 \\
Digested & 253 & 324 & 378 & & 1.5 & 0.02 & 0.30 \\
Urine & 79 & 122 & 165 & 2.7 & $<0.01$ & 0.91 \\
Milk & 131 & 141 & 151 & 2.4 & $<0.01$ & 0.88 \\
Retained in tissues & 41 & 59 & 59 & & 11.5 & 0.35 & 0.55 \\
\hline
\end{tabular}

${ }^{1}$ Least square means presented with pooled SEM (given for $\mathrm{n}=4$ ); $\mathrm{n}=5$ for low and medium HP and $\mathrm{n}=4$ for high MP.

${ }^{2}$ Probability corresponding to the null hypothesis with linear and quadratic contrasts. 
suggested (Harmeyer and Martens, 1980). As a result of decreased net PDV flux and increased hepatic flux of urea, the splanchnic net urea flux increased, which impacted both arterial urea concentration and elimination of $\mathrm{N}$ through the urine.

\section{Milk Production}

Increasing the $\mathrm{MP}$ supply by raising the $\mathrm{CP}$ content of the diet from 12.7 to $16.6 \%$ increased both milk production and milk protein yield, in agreement with earlier reports by Metcalf et al. (1996; 11.3 to $20.1 \% \mathrm{CP}$ ), Wright et al. (1998; 10.2 to $24.5 \%$ CP) and Dinn et al. (1998; 15.3 to $18.3 \%$ CP). In contrast, Castillo et al. (2001) reported no difference in milk production and composition with variation in CP content (14.0 to $18.3 \%$ $\mathrm{CP}$ ). On the other hand, Blouin et al. (2002) reported an increase in milk production and milk protein yield with fixed CP, and varied RUP. Nonetheless, changes in protein degradability and RUP supply alone do not explain variations in milk production responses (Santos et al., 1998). Together, these data clearly demonstrate that CP intake or RUP supply alone should no longer be used solely in dairy rations to evaluate the amount of protein delivered to the animal. Use of CP and RUP has now been superseded by the more informative use of MP, and now when earlier data are reevaluated by this approach, it is clear that changes in milk production related better to MP rather than to either $\mathrm{CP}$ or RUP. For example, increasing MP by $30 \%$ increased both milk production and milk protein yield (Metcalf et al., 1996; Wright et al, 1998; present study). In contrast, when MP supply was increased by $18 \%$, only milk production was improved (Dinn et al., 1998). In the study of Blouin et al. (2002), despite a similar CP intake, the additional supply in MP (16\%) generated by increasing RUP resulted in greater milk protein production. However, an increment in MP supply does not guarantee by itself an increment in milk production. In fact, Castillo et al. (2001), improved MP supply with increased $\mathrm{CP}$ or decreased protein degradability did not alter milk production because energy supply would have limited milk output to $22 \mathrm{~kg}$ (NRC, 2001).

\section{Nitrogen Balance}

The relatively small increase in fecal $\mathrm{N}$ compared with the additional $\mathrm{N}$ intake resulted in greater apparent $\mathrm{N}$ digestibility. Using a dynamic model based on 5 $\mathrm{N}$ balance studies with dairy cows, Kebreab et al. (2002) predicted that absolute metabolic fecal $\mathrm{N}$ would increase up to intakes of $420 \mathrm{~g}$ of $\mathrm{N} / \mathrm{d}$ and remain near constant thereafter. Therefore, the increased apparent $\mathrm{N}$ digestibility with increasing protein intake observed in the current study, as in previous reports (Wright et al., 1998; Castillo et al., 2000), would result from a decreased proportion of metabolic fecal $\mathrm{N}$ to total fecal $\mathrm{N}$ as $\mathrm{N}$ intake increased. Thus, with higher MP, more $\mathrm{N}$ is apparently digested and, if not used for anabolic purposes, more should be lost via urine rather than feces.

This is exactly what was observed, with the ratio of urinary $\mathrm{N}$ excretion to $\mathrm{N}$ intake increasing from 0.16 , 0.22 , and 0.26 for the low-, medium- and high-MP diets, respectively, similar to the observations of Wright et al (1998) and Dinn et al (1998). How much $\mathrm{N}$ is excreted in urine relates to a number of factors, including MP (or CP) intake, variations in the degradability of the ration and the ability of the cow to retain $\mathrm{N}$ for anabolic purposes. Indeed, when the anabolic potential is approached or exceeded, much of the extra digested $\mathrm{N}$ is excreted via urine. Thus, in the current study, although the extra digested $\mathrm{N}$ represented increases in portal absorption of both AA and ammonia, much of these were converted to catabolic endproducts (notably urea), with urinary N excretion increasing by more than $100 \%$ between low to high MP. As a result, the marginal return of digested $\mathrm{N}$ to milk was only 0.16 , compared with an apparent efficiency of 0.52 at the low MP supply. For other studies, where similar increases in digested $\mathrm{N}$ were achieved either by increased CP (Dinn et al., 1998) or protein degradability (Castillo et al., 2001 ), only 0.15 to 0.35 of the extra digested $\mathrm{N}$ was secreted as milk $\mathrm{N}$. These various data again reflect the declining return of milk output as maximal requirements are approached (Doepel et al., 2004).

\section{CONCLUSION}

In dairy cows receiving diets limited in protein supply (1922 g of MP/d or $12.7 \% \mathrm{CP}$ ), increased transfer of absorbed AA into milk protein occurred concomitantly with a reduction in hepatic removal of His, Met, Phe, and Thr, and a decreased catabolism/utilization of the BCAA, Lys, and Thr in peripheral tissues compared with higher MP supply. Therefore, to improve the prediction of protein supply and its utilization, it is necessary to appreciate the various metabolic events that occur between absorption and secretion in milk, to allow that the transfer of absorbed AA into milk is not fixed and will decrease as supply increases. Furthermore, it is important to take into account that these transfer factors vary widely between AA, as a consequence of both diet composition and metabolic events.

\section{ACKNOWLEDGMENTS}

The authors gratefully thank the staff of the Lennoxville dairy center for taking care of the animals, M. 
Léonard and S. Provencher for their dedicated technical support, D. St-Gelais and S. Haché for analyses of protein milk fractions, as well as S. Méthot for statistical analyses. The authors also wish to acknowledge the financial support of the Action Concertée Fonds FCAR = Novalait - MAPAQ, the National Science and Engineering Research Council of Canada, and Agriculture and Agri-Food Canada (Lennoxville Research Contribution number 829), as well as H. J. Baker \& Bro. Inc., for supplying the Pro-Lak bypass protein supplement.

\section{REFERENCES}

Amend, J. F., D. H. Strumeyer, and H. Fisher. 1979. Effect of dietary histidine on tissue concentrations of histidine-containing dipeptides in adult cockerels. J. Nutr. 109:1779-1786.

AOAC. Association of Official Analytical Chemists. 1996. Official Methods of Analysis. 16th ed. AOAC, Arlington, VA.

Bach, A., G. B. Huntington, S. Calsamiglia, and M. D. Stern. 2000. Nitrogen metabolism of early lactation cows fed diets with two different levels of protein and different amino acid profiles. J. Dairy Sci. 83:2585-2595.

Bequette, B. J., F. R. Backwell, J. C. MacRae, G. E. Lobley, L. A. Crompton, J. A. Metcalf, and J. D. Sutton. 1996. Effect of intravenous amino acid infusion on leucine oxidation across the mammary gland of the lactating goat. J. Dairy Sci. 79:2217-2224.

Blouin, J. P., J. F. Bernier, C. K. Reynolds, G. E. Lobley, P. Dubreuil, and H. Lapierre. 2002. Effect of supply of metabolizable protein on splanchnic fluxes of nutrients and hormones in lactating dairy cows. J. Dairy Sci. 85:2618-2630.

Calder, A. G., K. E. Garden, S. E. Anderson, and G. E. Lobley. 1999. Quantitation of blood and plasma amino acids using isotope dilution electron impact gas chromatography/mass spectrometry with U-(13)C amino acids as internal standards. Rapid Commun. Mass Spectrom. 13:2080-2083.

Calder, A. G., and A. Smith. 1988. Stable isotope ratio analysis of leucine and ketoisocaproic acid in blood plasma by gas chromatography/mass spectrometry. Use of tertiary butyldimethylsilyl derivatives. Rapid Commun. Mass Spectrom. 2:14-16.

Canadian Council on Animal Care. 1993. Guide to the Care and Use of Experimental Animals. Vol. 1. E. D. Offert, B. M. Cross, and A. A. McWilliam, eds. CCAC, Ottawa, Ontario.

Cant, J. P., E. J. DePeters, and R. L. Baldwin. 1993. Mammary amino acid utilization in dairy cows fed fat and its relationship to milk protein depression. J. Dairy Sci. 76:762-774.

Castillo, A. R., E. Kebreab, D. E. Beever, J. H. Barbi, J. D. Sutton, H. C. Kirby, and J. France. 2001. The effect of protein supplementation on nitrogen utilization in lactating dairy cows fed grass silage diets. J. Anim. Sci. 79:247-253.

DeSantiago, S., N. Torres, A. Suryawan, A. R. Tovar, and S. M. Hutson. 1998. Regulation of branched-chain amino acid metabolism in lactating rat. J. Nutr. 128:1165-1171.

Dinn, N. E., J. A. Shelford, and L. J. Fisher. 1998. Use of the Cornell net carbohydrate and protein system and rumen-protected lysine and methionine to reduce nitrogen excretion from lactating dairy cows. J. Dairy Sci. 81:229-237.

Doepel, L., D. Pacheco, J. J. Kennelly, M. D. Hanigan, F. P. Lṕpez, and H. Lapierre. 2004. Milk protein synthesis as a function of amino acid supply. J. Dairy Sci. 87:1279-1297.

Gill, J. L. 1978. Design and Analysis of Experiments in the Animal and Medical Sciences. Vol. 1. The Iowa State Press, Ames.

Goodwin, G. W., W. Gibboney, R. Paxton, R. A. Harris, and J. A. Lemons. 1987. Activities of branched-chain amino acid aminotransferase and branched-chain 2-oxo acid dehydrogenase complex in tissues of maternal and fetal sheep. Biochem. J. 242:305-308.
Hanigan, M. D., J. P. Cant, D. C. Weakley, and J. L. Beckett. 1998. An evaluation of postabsorptive protein and amino acid metabolism in the lactating dairy cow. J. Dairy Sci. 81:3385-3401.

Harmeyer, J., and H. Mertens. 1980. Aspects of urea metabolism in ruminants with reference to the goat. J. Dairy Sci. 63:1707-1728.

Huntington, G. B. 1984. Net absorption of glucose and nitrogenous compounds by lactating Holstein cows. J. Dairy Sci. 67:19191927.

Huntington, G. B., C. K. Reynolds, and B. H. Stroud. 1989. Techniques for measuring blood flow in splanchnic tissues of cattle. J. Dairy Sci. 72:1583-1595.

Jaubert, A., and P. Martin. 1992. Reverse phase HPLC analysis of goat caseins. Identification of $\alpha_{\mathrm{s} 1}$ and $\alpha_{\mathrm{s} 2}$ genetic variants. Lait 72:235-247.

Katz, M. L., and E. N. Bergman. 1969. A method for simultaneous cannulation of the major splanchnic blood vessels of the sheep. Am. J. Vet. Res. 30:655-661.

Kebreab, E., J. France, J. A. Mills, R. Allison, and J. Dijkstra. 2002. A dynamic model of $\mathrm{N}$ metabolism in the lactating dairy cow and an assessment of impact of $\mathrm{N}$ excretion on the environment. J. Anim. Sci. 80:248-259.

Lapierre, H., J. F. Bernier, P. Dubreuil, C. K. Reynolds, C. Farmer, D. R. Ouellet, and G. E. Lobley. 2000. The effect of feed intake level on splanchnic metabolism in growing beef steers. J. Anim. Sci. 78:1084-1099.

Lapierre, H., and G. E. Lobley. 2001. Nitrogen recycling in the ruminant: A review. J. Dairy Sci. 84:E223-E236.

Lapierre, H., E. Milne, J. Renaud, and G. E. Lobley. 2003. Lysine utilization by the mammary gland. Pages 777-780 in Progress in Research on Energy and Protein Metabolism. W. B. Souffrant and C. C. Metges, eds. EAAP Publication No. 109. Wageningen Academic Publishers, Wageningen, The Netherlands.

Lapierre, H., C. K. Reynolds, T. H. Elsasser, P. Gaudreau, P. Brazeau, and H. F. Tyrrell. 1992. Effects of growth hormone-releasing factor and feed intake on energy metabolism in growing beef steers: Net hormone metabolism by portal-drained viscera and liver. J. Anim. Sci. 70:742-751.

Lobley, G. E. 2002. Protein turnover-what does it mean for animal production? Pages 1-15 in Amino Acids: Meat, Milk and More! H. Lapierre and D. R. Ouellet, ed. CSAS Symposium, Québec, Canada.

Lobley, G. E., D. M. Bremner, and D. S. Brown. 2001. Response in hepatic removal of amino acids by the sheep to short-term infusions of varied amounts of an amino acid mixture into the mesenteric vein. Br. J. Nutr. 85:689-698.

Lobley, G. E., and H. Lapierre. 2003. Post-absorptive metabolism of amino acids. Pages 737-753 in Progress in Research on Energy and Protein Metabolism. W. B. Souffrant and C. C. Metges, eds. EAAP Publication No. 109. Wageningen Academic Publishers, Wageningen, The Netherlands.

Lobley, G. E., X. Shen, G. Le, D. M. Bremner, E. Milne, A. G. Calder, S. E. Anderson, and N. Dennison. 2003. Oxidation of essential amino acids by the ovine gastrointestinal tract. Br. J. Nutr. 89:617-630.

Mepham, T. B. 1982. Amino acid utilization by lactating mammary gland. J. Dairy Sci. 65:287-298.

Metcalf, J. A., D. Wray-Cahen, E. E. Chettle, J. D. Sutton, D. E. Beever, L. A. Crompton, J. C. MacRae, B. J. Bequette, and F. R. Backwell. 1996. The effect of dietary crude protein as protected soybean meal on mammary metabolism in the lactating dairy cow. J. Dairy Sci. 79:603-611.

Milano, G. D., A. Hotston-Moore, and G. E. Lobley. 2000. Influence of hepatic ammonia removal on ureagenesis, amino acid utilization and energy metabolism in the ovine liver. Br. J. Nutr. 83:307-315.

National Research Council. 2001. Nutrient Requirements of Dairy Cattle. 7th rev. ed. Natl. Acad. Sci., Washington, DC.

Ortigues-Marty, I., C. Obled, D. Darvedet, and I. Savary-Auzelux. 2003. Role of the liver in the regulation of energy and protein status. Pages 83-98 in Progress in Research on Energy and Protein Metabolism. W. B. Souffrant and C. C. Metges, eds. EAAP 
Publication No. 109. Wageningen Academic Publishers, Wageningen, The Netherlands.

Petit, H. V. 2002. Digestion, milk production, milk composition, and blood composition of dairy cows fed whole flaxseed. J. Dairy Sci. 85:1482-1490.

Pink, D., R. Elango, D. Dixon, and R. O. Ball. 2003. Lysine catabolism in the neonatal piglet during postnatal stages of growth and development. FASEB J. 17:A702. (Abstr.)

Raggio, G., G. E. Lobley, D. Pellerin, G. Allard, R. Berthiaume, P. Dubreuil, and H. Lapierre. 2002. Effect of protein intake on synthesis of albumin and plasma total protein in lactating dairy cows. J. Dairy Sci. 84(Suppl. 1):243. (Abstr.)

Reynolds, C. K., D. P. Casper, D. L. Harmon, and C. T. Milton. 1992 Effect of $\mathrm{CP}$ and $\mathrm{ME}$ intake on visceral nutrient metabolism in beef steers. J. Anim. Sci. 70(Suppl. 1):315. (Abstr.)

Reynolds, C. K., D. L. Harmon, and M. J. Cecava. 1994. Absorption and delivery of nutrients for milk protein synthesis by portaldrained viscera. J. Dairy Sci. 77:2787-2808.

Santos, F. A., J. E. Santos, C. B. Theurer, and J. T. Huber. 1998. Effects of rumen-undegradable protein on dairy cow performance: A 12-year literature review. J. Dairy Sci. 81:3182-3213.

SAS User's Guide. Statistics. Edition 1996. SAS Inst., Inc., Cary, NC.
Susmel, P., M. Spanghero, B. Stefanon, and C. R. Mills. 1995. Nitrogen balance and partitioning of some nitrogen catabolites in milk and urine of lactating cows. Livest. Prod. Sci. 44:207-219.

Swaisgood, H. E. 1995. Protein and amino acid composition of bovine milk. Pages 464-468 in Handbook of Milk Composition. R. G. Jensen, ed. Academic Press, Toronto, ON.

Thivierge, M. C., J. F. Bernier, P. Dubreuil, and H. Lapierre. 2002. The effect of jugular or abomasal infusion of amino acids on milk yield in lactating cows fed a protein deficient diet. Reprod. Nutr. Dev. 42:1-13.

Vanhatalo, A., P. Huhtanen, V. Toivonen, and T. Varkikko. 1999. Response of dairy cows fed grass silage diets to abomasal infusions of histidine alone or in combination with methionine and lysine. J. Dairy Sci. 82:2674-2685.

Wray-Cahen, D., J. A. Metcalf, F. R. Backwell, B. J. Bequette, D. S. Brown, J. D. Sutton, and G. E. Lobley. 1997. Hepatic response to increased exogenous supply of plasma amino acids by infusion into the mesenteric vein of Holstein-Friesian cows in late gestation. Br. J. Nutr. 78:913-930.

Wright, T. C., S. Moscardini, P. H. Luimes, P. Susmel, and B. W. McBride. 1998. Effects of rumen-undegradable protein and feed intake on nitrogen balance and milk protein production in dairy cows. J. Dairy Sci. 81:784-793. 